\title{
Street Children Phenomenon in Makassar City : A Criminological Analysis
}

\author{
Nur Fadhilah Mappaselleng \\ Universitas Muslim Indonesia, Indonesia, E-mail:nurfadhilahmappaselleng@gmail.com
}

Submitted: March 10, 2020; Reviewed: April 13, 2020; Accepted: August 10, 2020

\begin{tabular}{|c|c|}
\hline Article Info & Abstract \\
\hline $\begin{array}{l}\text { Keywords: } \\
\text { Criminology, Makassar City, Street } \\
\text { Children } \\
\text { DOI: } \\
\text { 10.25041/fiatjustisia.v15no1.1915 }\end{array}$ & $\begin{array}{l}\text { The presence of children who live on the streets has } \\
\text { caused concern in various cities in Indonesia, } \\
\text { especially Makassar, South Sulawesi. Lack of } \\
\text { education, decent life, and government attention } \\
\text { trigger street children to do unlawful acts, such as } \\
\text { drugs and drinking. From a criminological } \\
\text { perspective, the phenomenon of street children can be } \\
\text { explained using the social learning theory. Social } \\
\text { learning theory is a convergence between differential } \\
\text { association theory with general behavioural } \\
\text { principles, which in this theory explains that criminal } \\
\text { behaviour can be obtained from environmental } \\
\text { influences. There is a reciprocal interaction that } \\
\text { directs a person's behaviour. This study aims to } \\
\text { determine the description of street children's existence } \\
\text { in the city of Makassar, analyse the factors that cause } \\
\text { the phenomenon of street children, and determine the } \\
\text { prevention of street children. The research method } \\
\text { uses a type of qualitative research sourced from the } \\
\text { various scientific literature. This study indicates that } \\
\text { the phenomenon of street children is a warning } \\
\text { signalling the need for social development and poverty } \\
\text { eradication policies to improve the situation on the } \\
\text { broader community and prevent more young people } \\
\text { from becoming marginalised. Every child must be } \\
\text { protected according to United Nations Children's } \\
\text { Fund and also has been regulated in Regional } \\
\text { Regulation No. } 2 \text { of } 2008 \text { concerning the Development } \\
\text { of Street Children, Homeless, Beggars and Buskers in } \\
\text { Makassar City. }\end{array}$ \\
\hline
\end{tabular}




\section{A. Introduction}

Children are the trust and blessings of Almighty God, which must always be guarded. Every child has inherent dignity and rights as human beings that must be upheld. This is because it is also in the hands of the children who will be determined. The appearance of street children sometimes comes from an inappropriate life. Le Roux stated that life on the streets is a response experienced by families who live in unfavourable conditions. Children tend to leave their homes and families and live in the streets to do whatever they want regardless of existing norms. ${ }^{1}$

The phenomenon of street children in Indonesia began in the mid-1980s. The existence of economic centralisation and development, which continues to develop, is a factor in the increasing poverty rate. The government focuses on urban communities, while development in rural areas is ignored. The increasing number of street children was supported by the collapse of the Indonesian economy in the 1990s when according to the World Bank, the poverty rate in Indonesia in 1999 increased from under \$ 1 per day to more than double. ${ }^{2}$

Based on the Social Welfare Data and Information Center by the Ministry of Social Affairs, the number of street children has decreased. In 2006 there were 232,894 children, in 2010 there were 159,230 children, in 2011 there were 67,607 children, and in 2015 there were 33,400 children. According to Makassar City Social Service Data, in 2016, the number of street children increased to 1000 children, different from the previous years of around 500 children. ${ }^{3}$

Makassar city, like other cities in Indonesia, also experienced the same thing related to the proliferation of street children in the corners of the city. Makassar, which has grown rapidly in eastern Indonesia, has become a magnet for people in areas around Makassar, which has led to migration and high population mobilisation. Limited employment opportunities cause the growth of urban communities that are poor and do not have permanent jobs. In the city of Makassar street children are apparent, especially in public places such as at the junction of the Reformasi Toll road, Andi Pangeran Pettarani Street and Sultan Alauddin Street, the crossroads of Masjid Raya and Gunung Latimojong Street, the intersection of Sungai Saddang and Veteran Street, intersection Monginsidi and Veteran Street, intersection Landak Baru and

\footnotetext{
${ }^{1}$ Amanda Friberg, "Problem and Solutions when Dealing with Street Children", Candidate Thesis of School of Health and Welfare, Jonkoping University, (2017): 23.

${ }^{2}$ Lilis Mulyani, "Street Children And Broken Perception : A Child's Right Perspectives", Jurnal Masyarakat Indonesia 37, no. 2 (2011): 177-198, 179.

${ }^{3}$ Azhary Adhyn Achmad, et al. "Fenomena "Ngelem" Oleh Anak Jalanan di Kota Makassar", Jurnal Penelitian \& PPM 4, no. 2 (2017): 361.
} 
Veteran Street. ${ }^{4}$ In strategic places such as crossroads, malls, cafes, restaurants, shopping centres and other public facilities, it is not difficult to find children who in various ways, do a business to earn money. Street children in Makassar come from various parts of South Sulawesi, such as Maros, Pangkep, Gowa, Jeneponto and from various cities outside Makassar, from Java, Lombok and Kalimantan. ${ }^{5}$ This condition can enable children to be the object of exploitation and trafficking, so it is interesting to explore more deeply and at the same time be able to know that the existence of street children is one of the social vulnerabilities that will have an impact on criminology. This study aims to determine how the description of the existence of street children in Makassar, what factors cause the phenomenon of street children, and efforts in tackling street children.

This article uses qualitative research. Qualitative research challenges the reality of street children by revealing their behaviour on the streets. The basis of qualitative research lies in the interpretive discussion of social reality, specifically street children and not generalising. The population in this study was all street children found in Makassar, while the samples taken were those found on public roads such as malls, intersections, and shopping centres. Determination of Snowball samples (finds a person or group of street children and then move increasingly to other groups). Data is collected using collections or close collection with street children. In possible discussions, an interview technique will be conducted to discuss their perspectives about the reasons for their activities on the streets and their background in life. Data analysis is carried out dynamically and interconnected between the components of data reduction, data presentation, verification, or conclusion.

\section{B. Discussion}

\section{Current Phenomenon of Street Children}

The concept of street children, in general, originates from the development of children in the family. There are several concepts of how a child can live on the streets. First, the majority of children work in the streets and return home and meet their families at night. Second, children who are on the streets may not have a good relationship with their families and prefer to spend their time on the streets. Finally, children choose to live and live on the streets and leave their families. The definitions above show that the existence of street children does not appear without reason, and most of these reasons

\footnotetext{
${ }^{4}$ Ronawaty Anasiru, "Implementasi Model-Model Kebijakan Penanggulangan Anak Jalanan di Kota Makassar", Jurnal Sosiokonsepsia 16, no. 2 (2011): 175-186, 176.

${ }^{5}$ Desy Merdiana Papalapu, "The Role of The Departmennt of Social In Empowering The Street Children in Makassar", IJER 13, no. 1 (2016): 101-113, 102.
} 
are due to disharmony in the relationship between children and their parents and family. ${ }^{6}$

A street child, as defined by United Nations Children's Fund (UNICEF), is one for whom the street (in the broadest sense of the word, such as unoccupied dwellings, wasteland, etc.) more than their family has become their real home, a situation in which there is no protection, supervision, direction from responsible adults. ${ }^{7}$ The streets are the main destination for children leaving their homes. For UNICEF, street children are often referred to as neglected children. UNICEF believes that these street children and neglected children are most likely to make a living illegally, namely:

"They become premature adults and develop behaviour patterns which can be summarised in a rejection of authority, aggressiveness, and absence of limits, independence and a lack of affection. They are also characterised by problems with drug addiction, alcoholism, delinquency, prostitution and moral and physical abuse." 8

\section{Street Children's Growth in Makassar City}

Street children in Makassar City are grouped into several categories. First, children who work on the streets and have a family or place to live. Most of the street children from this category work as hawkers, such as selling tissue, drinks, newspapers, and so on. Meanwhile, the second is children who have lived on the streets as a result of disharmony with their parents and family. They live on the streets, work on the streets, join the community who have lived on the streets for a long time. ${ }^{9}$ The data from the Makassar City Social Service shows that in 2018, the number of street children, homeless people and beggars decreased, which according to the Saribbattang Rapid Reaction Team (TRC) Razia, there were 511 people compared to 2017 of 1,050 people. Meanwhile, in early January to August 2019, 269 people who were on the streets were netted. The street children patrol conducted by the Makassar City Social Service Data focuses on 11 locations, such as around Fly Over, Andi Pangeran Pettarani Street, Boulevard road, Pengayoman Street, Andi Tonro Street, Veteran Street, Andi Djemma Street, Saddang River Street, Arif Rate Street, Jalan Adiyaksa and around the Grand Mosque.

\footnotetext{
${ }^{6}$ Ibid.

${ }^{7}$ Jessica Woan, The Health Status of Street Children and Youth in Low and Middle Income Countries : A Systematic Review of the Literature", Journal of Adolescent Health 53, (2013): 314-321, 314, DOI: 10.1016/j.jadohealth.2013.03.013.

${ }^{8}$ Kevin Lalor, "Street Children : A Comparative Perspective", Child Abuse and Neglect 23, no. 8 (1999): 759-770, 760, https://doi.org/10.1016/s0145-2134(99)00047-2.

${ }^{9}$ Ipandang, "'Maqashid Al-Sharia' Perspective for Character Building among Street Children In Makassar, South Sulawesi”, Al-Ulum 15, no. 2 (2015): 335-350, 341, DOI: https://doi.org/10.30603/au.v15i2.205.
} 
Meanwhile, at the end of 2019, there was an increase in the number of 332 street children and beggars. Most of these street children work as sellers of sweets, tissues, books, religious stickers, buskers, traffic controllers. ${ }^{10}$

It is indeed difficult to obtain precise data on the number of street children. The problem lies in the fact that street children are an unstable social phenomenon. It could be that one time has increased but at other times has decreased. It depends on the socioeconomic situation where they come from. They generally come from areas around Makassar City. If economic opportunities in their homes allow, they will abandon their activities to "get off the road".

Nevertheless, when economic opportunities decrease, then they will emerge again. They will also move between good or heavy weather to do activities on the streets. In addition, the times when the community's habit of giving alms are taken into account. Ramadan and certain other months where there are days of worship and crowds are also a consideration. In the month of Ramadan and Eid are the days where the activities of children making a living on the road will increase. To the extent that there is an appeal from the relevant parties so that the community "does not give alms on the road". Alms on the road is not prohibited in terms of religion, but the ethics of giving something in an educative way so that children are not dependent on others. This is more important is not to harm yourself because of the risk of activities on the streets.

Repressive actions cannot be carried out by the Makassar City government. The law owned is only limited to the Regional Regulations of Makassar City Number 2 of 2008 concerning the Development of Street Children, Homeless, Beggars and Buskers in Makassar City. The essence of this regulation is the provision of guidance to street children, etc. Article 6 paragraph 1 of this regulation states that guidance is carried out through data collection, monitoring, control and supervision, socialisation and campaigns. ${ }^{11}$ This guidance is carried out by individuals, families, community organisation groups, social organisations and related agencies.

Furthermore, Article 8 states that coaching is carried out with the aim of, among others, providing protection and creating order and peace of society. This is done in the context of upholding human rights and dignity and dignity as citizens who must be respected, increasing order in society through legal certainty that can protect citizens so they can live in peace and peace. The regulations do not mention any sanctions that can be imposed on perpetrators, other than coaching steps, as mentioned above.

\footnotetext{
${ }^{10}$ Tuti Bahfiarti, "Communication Behaviour of Street Children and Beggars in Makassar", Etnosia: Jurnal Etnografi Indonesia 4, no. 2 (2019): 163-175, 164 DOI: http://dx.doi.org/10.31947/etnosia.v4i2.7377.

${ }^{11}$ Regional Regulation of Makassar City Number 22008 Concerning The Development Of Street Children, Homeless People, Beggars And Buskers
} 


\section{Causes and Factors}

One of the reasons children are on the streets in poverty. In addition, several other factors include street children, namely death, displacement, drug use, and so on. ${ }^{12}$

In Lalor's opinion, the main factors that encourage children to leave their homes are child abuse and neglect, after family disintegration, parental separation or divorce, parental death, or remarriage. After the parents' remarriage, children are often abused and forced to leave home by stepfathers or mothers, such as lack of food, overwork, nagging, and physical beatings. One of the problems children face when living with family or guardians or others is abusive behaviour. Children's families make abuse against their children as a result of various factors including being a stepfather or mother, alcoholic behaviour, conflicts in the family and the like. Therefore, such abusive behaviour forces children to leave their families and homes to take to the streets. As a result, street children were asked whether they were abused or not and by whom they were abused. ${ }^{13}$

Therefore, there are several risks and effects of children being on the streets ${ }^{14}$ :

a. Violence Against Street Children

Living alone on the streets without any protection from parents or family makes children on the streets very vulnerable to harassment and discrimination, by being enslaved, being used, being made into objects of violence by a group of people who have been in the street environment for a longer time.

b. Grouping Street Children Into a Gang

This kind of grouping triggers street children to commit criminal acts in groups.

c. Street Children Can Become Addicted to Drugs

Some street children choose to be involved in drug use to survive on the streets, trauma, disease, hunger, stigmatisation, and nationality.

d. Street Children Can Suffer From Mental Health Problems

Street children suffer from depression, casualties, and trauma, which in turn can lead to illness and risk of suicide.

\section{Criminological Analysis of Street Children}

\footnotetext{
${ }^{12}$ End Child Poverty Category. 2016. Myth Busters: What You Know About Street Children. https://endingchildpovery.org/en/blog/177-myth-busters-what-you-know-about-streetchildren, Accessed on January 11, 2020.

${ }^{13}$ Tesfaye Diriba, "Family Problem as a Contributing Factors for Street Children. The Case of Nekemte Town", IJRSI 2, no. 9 (2015): 136-144, 137.

${ }^{14}$ Conssortium For Street Children. 1993. Street Children Are One of The Most Vulnerable Children on The Planet. https://www.streetchildren.org/about-street-children/. Accessed on January 9, 2020.
} 
Not without reason, many children live on the streets for a living. The rise of street children also causes a variety of crimes that occur on the road, both theft, drugs, which are caused due to the lack of government attention and legal entities related to street children which increases every year. The discussion on the factors of the rise of crime by street children makes criminological theory important to discuss. Criminology itself is a science that discusses crime as a social phenomenon, including the process of making laws, violations of the law and how it reacts to violations of the law. Because of the various questions regarding the notion of criminology, some people consider that criminology is not an independent discipline. However, as stated by Paul Rock, criminology is a field of study. The subject of the meeting where various disciplines meet with each other around the topic of crime. Criminology is a multidisciplinary framework whose focus is dominated by questions about crime and justice.

The phenomenon of street children in criminological aspects can be related to social learning theory. Social Learning Theory triggered by Ronald L. Akers explains that:

"The probability that persons will engage in criminal and deviant behaviour is increased and the probability of their conforming to the norm is decreased when they differentially associate with others who commit criminal behaviour and espouse definitions favourable to it, are relatively more exposed in person or symbolically to salient criminal/deviant models, define it as desirable or justified in a situation discriminative for the behaviour, and have received in the past and anticipate in the current or future situation relatively greater reward than punishment for the behaviour. "15

According to Akers, there are four types of premises in social learning theory, namely differential association, definitions, differential reinforcement, and imitation. ${ }^{16}$

Edwin H. Sutherland defines Differential Associations as the content of the patterns presented in associations. This does not mean that only association with criminals will lead to criminal behaviour, but what is important is the content of the communication process from others. In the social context, various kinds of situations behave in both positive and negative behaviour, which are acceptable or unacceptable by society. The behaviour of street children, in this case, will be formed by itself along with their growth in the neighbourhood where they live. ${ }^{17}$

\footnotetext{
15 Jonathan R. Brauer, "Social Learning Theory and Human Reinforcement", Sociological Spectrum 32, no. 2 (2012): 157-177, 159, https://doi.org/10.1080/02732173.2012.646160.

${ }^{16}$ Nur Fadhilah Mappaselleng, Zul Khaidir Kadir, Kriminologi: Esensi dan Perspektif Arus Utama (Yogyakarta: Trussmedia Grafika, 2017), 177.

17 Scot Wortley, The Root Causes of Youth Violence: A Review of Major Theoretical Perspectives (Toronto: Ontario Publications, 2008), 100.
} 
Regarding definitions, in Social Learning theory, there are general and specific definitions. The discussion of this general definition is more directed at how humans should live in the world, namely adjusting all behaviour to existing norms and not deviating from religious or moral values. This means that the community will obey all the rules and not take any illegal or deviant actions. But, in a specific definition, it refers to someone who performs a certain Action. Someone can easily commit a criminal act or deviates if there are more supporting factors for committing the act, so too. The combination of these two definitions makes street children's behaviour categorised into two kinds, which are the acceptable ones and the unacceptable one's ${ }^{18}$ Street children, perhaps, do not commit criminal acts because they know that these actions are legally wrong. Still, at the same time, they do not see any moral errors and choose to smoke, drugs, get drunk.

Next, differential reinforcement, where individuals learn and anticipate the consequences of their actions. The actions they take depend on how much punishment and rewards they will get in the past, present, and future. Rewards and punishments are obtained in the form of social and non-social experiences, either experienced or anticipated. The possibility that happens is when someone commits a criminal act and gets a reward, for example, getting money, the action may be repeated continuously. Conversely, when a person is found to have committed a criminal act and gets a punishment accordingly, the consequences of this action will be anticipated so that it will not be repeated in the future.

And the last, imitation. The closeness between individuals results in easily following each other's behaviour (continuous reciprocal interaction). ${ }^{19}$ Basically, social learning theory has been used to prevent and treat crime and delinquency. A basis of social learning theory is that both delinquent and conventional behaviour can be learned, especially towards street children.

\section{Handling of Street Children in Makassar}

The treatment of street children can be categorised into four types, namely interventions that are road-centred, family-centred interventions, interventions centred on institutions, and interventions that are centred on communities. First, interventions centred on the road, by going directly to the places where street children are. This intervention model aims to make a direct approach to street children. Second, family-centred interventions, by providing social assistance to families in need to suppress the growth of street children. Third, interventions centred on institutions, with the establishment of tamping houses for street children and providing health insurance. Fourth,

\footnotetext{
${ }^{18}$ Ibid., 101.

${ }^{19}$ Caitlin M. Brady, The Encyclopedia of Juvenile Delinquency and Justice (New York: John Wiley \& Sons Inc, 2017), 1.
} 
community-centred interventions, involving community empowerment institutions, both NGOs and government agencies.

In addition, the things that can be done by law enforcement agencies in dealing with street children are as follows:

1. Legislation Promotion. One of the laws that must be socialised intensively is Law Number 35 of 2014 concerning Child Protection. Article 88 of the law states: "Everyone who violates the provisions referred to in article 76 (1), is sentenced to a maximum imprisonment of 10 years and a maximum fine of Rp. 200,000,000.00 (two hundred million rupiahs) ". The socialisation of this law can be done by drafting banners, billboards, and so on that put this article in a vulnerable place or often found street children begging.

Another law that needs to be socialised is Law Number 4 of 1979 concerning Child Welfare. The rights of children contained in Article 2 to Article 8 .

\section{Article 2}

(1) The child has the right to welfare, care and guidance.

(2) Children have the right to serve to develop their abilities and social life, by the culture and personality of the nation, to become good and useful citizens.

(3) Children have the right to care and protection, both in the womb and after birth.

(4) The child has the right to protection of the environment that can harm or hinder the natural growth

\section{Article 3}

In dangerous situations, children are the first to be entitled to help, assistance, and protection.

\section{Article 4}

(1) Children who do not have parents are entitled to care by the state or person or entity.

(2) The implementation of the provisions in paragraph (1) shall be regulated further by government regulation.

\section{Article 5}

(1) Children who are unable to have the right to receive assistance so that in their family environment can grow and develop properly.

(2) The implementation of the provisions in paragraph (1) shall be regulated further by government regulation.

\section{Article 6}

(1) Children who experience behavioural problems are given services and care aimed at helping them to overcome obstacles that occur during their growth and development. 
(2) Services and care, as referred to in paragraph (1) are also provided to children who have been found guilty of violating the law based on a judge's decision.

\section{Article 7}

Children with disabilities receive special services to reach the level of growth and development as far as the ability and ability of the child concerned Article 8

(1) Assistance and services, which aim to make child welfare the right of every child without discriminating gender, religion, political standing, and social position.

(2) Improving community welfare through community empowerment programs for people with low education.

(3) Routine patrol by the government in this case the Social Service together with the police to places that are prone to crime related to street children.

\section{Conclusion}

Based on the previous description the author then concludes in accordance with the main issues identified that the factors that cause the crime of exploiting children as street beggars are economic factors, urbanisation factors, factors of lack of concern for the government and the community in protecting and fulfilling children's rights and weak law enforcement for street children in Makassar City. The effort that can be made in dealing with street children is the socialisation of Law No. 35 of 2014 concerning Child Protection, particularly in article 88 of the law, Dissemination of Law No. 4 of 1979 concerning Child Welfare, as well as routine patrols by the government and other parties concerned with children's rights to places prone to a crime that exploit children as street beggars. 


\section{References}

Anasiru, Ronawaty. "Implementasi Model-Model Kebijakan Penanggulangan Anak Jalanan di Kota Makassar". Jurnal Sosiokonsepsia 16, no. 2, 2011: 175-186.

Bahfiarti, Tuti. "Communication Behaviour of Street Children and Beggars in Makassar". Etnosia: Jurnal Etnografi Indonesia 4, no. 2, 2019: 163175, DOI: http://dx.doi.org/10.31947/etnosia.v4i2.7377.

Brauer, Jonathan R. "Social Learning Theory and Human Reinforcement". Sociological Spectrum 32, no. 2, 2012: 157-177, https://doi.org/10.1080/02732173.2012.646160.

Conssortium For Street Children, "Street Children Are One of The Most Vulnerable Children on The Planet", 1993, https://www. streetchildren.org/about-street-children/. Accessed on January 9, 2020.

Diriba, Tesfaye. "Family Problem as a Contributing Factors for Street Children. The Case of Nekemte Town". IJRSI 2, no. 9, 2015: 136144.

End Child Poverty Category, "Myth Busters: What You Know About Street Children”, 2016, https://endingchildpovery.org/en/blog/177-mythbusters-what-you-know-about-street-children, Accessed on January $11,2020$.

Friberg, Amanda. "Problem and Solutions when Dealing with Street Children". Candidate Thesis of School of Health and Welfare, Jonkoping University, 2017.

Ipandang. "Maqashid Al-Sharia' Perspective for Character Building among Street Children In Makassar, South Sulawesi". Al-Ulum 15, no. 2, 2015: 335-350, DOI: https://doi.org/10.30603/au.v15i2.205.

Jamiludin, et al. "Street Children's Problem in Getting Education : Economic and Parental Factors". Mediterranean Journal of Social Sciences 9, no. 1, 2018: 103-108, DOI: 10.2478/mjss-2018-0010.

Lalor, Kevin. "Street Children : A Comparative Perspective". Child Abuse and Neglect 23, no. 8, 1999: 759-770, https://doi.org/10.1016/s01452134(99)00047-2.

Mappaselleng, Nur Fadhilah., Kadir, Zul Khaidir. Kriminologi : Esensi dan Perspektif Arus Utama. Yogyakarta : Trussmedia Grafika, 2017.

Mulyani, Lilis. "Street Children And Broken Perception: A Child's Right

Perspectives", Jurnal Masyarakat Indonesia 37, no. 2, 2011: 177-198.

Ozbas, Mehmet. "Personal and Familial Properties of Street Children-Street Children: The Forgotten or Not Remembered Ones". Journal of Education and Learning 4, no. 1: 97-107, DOI: 10.5539/jel.v4n1p97. Papalapu, Desy Merdiana. "The Role of The Departmennt of Social In Empowering The Street Children in Makassar". IJER 13, no. 1, 2016 : 101-113. 
Regional Regulation of Makassar City Number 2 (2008) Concerning the Development of Street Children, Homeless People, Beggars And Buskers

Woan, Jessica. "The Health Status of Street Children and Youth in Low and Middle Income Countries : A Systematic Review of the Literature". Journal of Adolescent Health, 53, 2013: 314-321, DOI: 10.1016/j.jadohealth.2013.03.013.

Wortley, Scot. The Root Causes of Youth Violence: A Review of Major Theoretical Perspectives. Toronto: Ontario Publications, 2008. 